\title{
BOTRYTIS FRUIT ROT AND MICROFUNGAL POPULATIONS ON CONVENTIONALLY AND ORGANICALLY PRODUCED STRAWBERRIES
}

\author{
N.W. WAIPARA ${ }^{1}$ and M. TORP ${ }^{2}$ \\ ${ }^{1}$ HortResearch, P.O. Box 51, Lincoln, New Zealand \\ ${ }^{2}$ National Veterinary Institute, Pb 8156, Dep0033, Oslo, Norway \\ Corresponding author: nwaipara@hortresearch.co.nz
}

\begin{abstract}
A survey to determine the biodiversity of microfungi, particularly spoilage and fruit rot causing species, was undertaken for both organically and conventionally produced strawberries. Both superficial surface colonisation and systemic internal colonisation of the berries by all microfungi was examined. Strawberry fruit rot, caused by Botrytis cinerea (Grey mould disease), was present in all fruit samples but total isolation frequencies were significantly higher in conventionally produced berry samples than organic samples. Surface colonisation by Botrytis was higher in organic samples but disease expression was lower than that observed in conventional samples. In contrast systemic infection was higher in all conventional samples. The fruit spoilage fungi, Mucor and Rhizopus, were isolated with similar frequency from organic and conventional samples. Additional strawberry pathogens were also isolated in the survey, Colletotrichum gloeosporioides (anthracnose fruit rot), Idriella lunata (root rot) and Rhizopus stolonifer (leak disease). Botrytis suppressive fungi, Aureobasidium pullulans, Epicoccum nigrum and Ulocladium sp., were more frequently isolated from organic berries and have potential as biocontrol antagonists.
\end{abstract}

